\title{
Assessment of woody plant species composition in secondary deciduous forests of Odisha, India
}

\author{
Subhashree Pattnayak \\ School of Life Sciences, Sambalpur University, Jyoti Vihar, Odisha, India \\ Rajendra Kumar Behera \\ School of Life Sciences, Sambalpur University, Jyoti Vihar, Odisha, India \\ Sudam Charan Sahu \\ Department of Botany, Maharaja Sriram Chandra Bhanja Deo University, Baripada, Odisha, India \\ Nabin Kumar Dhal \\ Environment and Sustainability Department, CSIR- Institute of Mineral and Material Technology, Bhubaneswar, Odisha, India
}

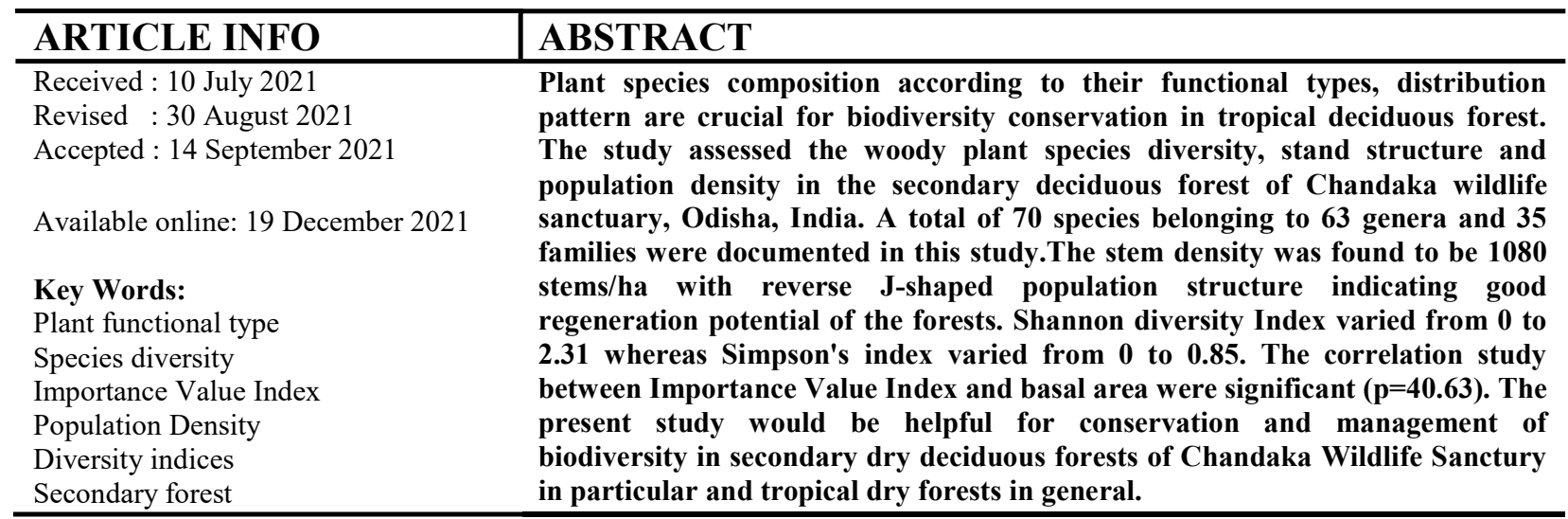

\section{Introduction}

Tropical forests are vital for sustainable changes in species composition, and reduces the development, and significant natural habitat for frequency and density of tree species. The species conservation (Djuikouo, 2010). The global deforestation and forest degradation account $25 \%$ forest account approximately $31 \%$ of its land area $\left(8.2 \mathrm{Gt} \mathrm{CO}_{2}\right.$ emission per year) of total world $\mathrm{CO}_{2}$ (FRA, 2020). The tropical forest occupies around emission (Pearson et al., 2017). During 1990 the $60 \%$ of the biotic species within its 7\% land cover loss of forest was 420 million ha, but the rate has (Galley, 2014). The forest primary vegetation that been declined extensively to 10 million ha in the comes under the plant functional types (PFTs) is recent years 2015-2020 due to the addition of 93\% representing the variety and heterogeneity of the regenerating forest and $7 \%$ planted area (FAO, hierarchy of life and stability of the vegetation. The 2020). These also resulted the increase of the tree vegetation here is the principal structural and secondary forest mostly around the tropical region functional basis and indicators of changes at the landscape level. On the contrary, Deforestation due to traditional slash, industrial expansions, illegal logging, and mining activities, the building of wood fiber products causes $35 \%$ of forest loss simultaneously the loss of biodiversity and change ecosystem balance (Chazdon and Guariguata, 2016). This has disrupted the forest structure, which are a rich source of medicinal, economically important plants (Armentaras et al., 2009; Haripriya, 2000) and provide forest products and fodder, cultural values, and carbon regulatory services (Lazos-Chavero et al., 2016; Tauro et al., 2018). Hence, the assessments of species compositional and functional dimensions of forest area are necessary. The potential understanding of

Corresponding author E-mail: gnature53@gmail.com

Doi: https://doi.org/10.36953/ECJ.2021.22338

This work is licensed under Attribution-Non Commercial 4.0 International (CC BY-NC 4.0)

(C) ASEA 
plant diversity and composition are the fundamental attributes of forest conservation management and are the quantitative derivation of plant diversity. The diversity indices assess the ecological mechanisms that are affecting biodiversity. There is no single and specific index to quantify and summarize the concept of species composition and assessments. Some of the matrices like Species richness (Purvis and Hector, 2000), Shannon diversity and Simpson diversity indices are convenient method for the theoretical interpretation of species diversity of the forest. Several qualitative assessments had conducted in the tropical forest of Western Ghats (Chittibabu and Parthasarathy, 2000; Jayakumar and Nair, 2003). But the information regarding the plant distribution, structure and composition of tree species, and their plant functional types including above-ground biomass in the tropical deciduous forest of Eastern Ghats is lacking (Panda, 2013; Reddy et al., 2011; Sahu et al., 2007). The part of Eastern Ghats spread from the north-west of Mayurbhanj to the southwest of Malkangiri of Odisha, India. Chandaka forest is located in the North-eastern edge of Eastern Ghats, India, and was classified as a semievergreen forest (Biswal et al., 2005).

Due to anthropogenic activities, several patches within the Chandaka forest transformed into shrub jungles and thorny bushes. Thus in the year 1983, the Chandaka forest is declared as a sanctuary for restoration and cited as a secondary regenerated deciduous forest. The present study aimed to the species diversity among the six plant functional types (PFTs) and analyzed different structural parameters for a better ecological understanding of tropical secondary deciduous forests. The study could establish the significance and differences of plant basal area, stem density influencing Importance Value Index (IVI)and forest stand structure.

\section{Material and Methods \\ Study area}

Chandaka Wildlife Sanctuary (CWS) covers with small sprawling hillocks of Khurdha and Cuttack districts of Odisha. It is situated between $20^{\circ} 12^{\prime}$ $30^{\prime \prime} \mathrm{N}$ to $20^{\circ} 26^{\prime} 03^{\prime \prime} \mathrm{N}$ latitude to $85^{\circ} 49^{\prime} 35^{\prime \prime} \mathrm{E}$ to $85^{\circ} 34^{\prime} 42^{\prime \prime} \mathrm{E}$ longitude (Fig.1). Basing on the species composition, vegetation type, and dominant species prevailing areas, the forest is divided into the following Plant Functional Types (PFTs) namely: Northern Secondary Moist Mixed Deciduous Forest (MMDF), Peninsular Sal Forest (PSF), Semi-evergreen Forest (SEF), Planted Teak Forest (PTF), Bamboo brakes (BB) and Degraded Thorny Shrubby Forest (DTSF) (Figure 1).

\section{Sampling sites and plant collection:}

Plants were collected every month from May 2015 to March 2017. A total of 24 sampling plots $(50 \mathrm{~m}$ x $20 \mathrm{~m}$ size) were laid randomly, and the size of sampling plots was decided based on the speciesarea curve (Mueller-Dombois and Ellenberg, 1974). The entire woody plant species $\geq 10 \mathrm{~cm}$ Girth at Breast Height $(\mathrm{GBH})$ was measured. The spatial plot locations (latitude and longitude of each plot) were tagged by GARMIN- Global Positioning System (GPS).The collected Plants' twigs (leaves, flowers, fruits, etc.) from the sampling plots brought to the laboratory for their species-level identification and herbarium preparation using Flora of Orissa (Saxena and Brahmam, 1996).

Vegetation structure analysis and distribution The density, basal area, and Importance Value Index of the trees and shrubs were calculated. Likewise, species distribution was determined through the ratio of abundance and frequency. The value $<0.025$ is for regular, 0.025-0.05 for random and $>0.05$ for contagious distribution (Ndah et al., 2013). The formulas are mention below

$$
\begin{aligned}
& \text { Density }=\frac{\text { No.of individuals of a species in all quadrats }}{\text { Total number of quadrats studied }} \\
& \text { Frequency }(\%)=\frac{\text { No.of quadrats in which a species occur }}{\text { Total number of quadrats studied }} \times 100 \\
& \text { Abundance }=\frac{\text { No.of individuals of a species in all quadrats }}{\text { No.of quadrats in which species occur }} \\
& \text { Distribution pattern }=\frac{\text { Abundance }}{\text { Frquency }} \\
& \text { Relative Frequency }(\mathrm{RF})=\frac{\text { Number of occurrence of species }}{\text { Number of occurrence of all the species }} \times 100 \\
& \text { Relative Density (RD) }=\frac{\text { Number of Individual of the species }}{\text { Number of individuals of all species }} \times 100 \\
& \text { Relative Dominance (RDo) }=\frac{\text { Total basal area of the species }}{\text { Total basal area of all the species }} \times 100
\end{aligned}
$$

Importance Value Index (IVI) $=$ RD + RDo + RF 


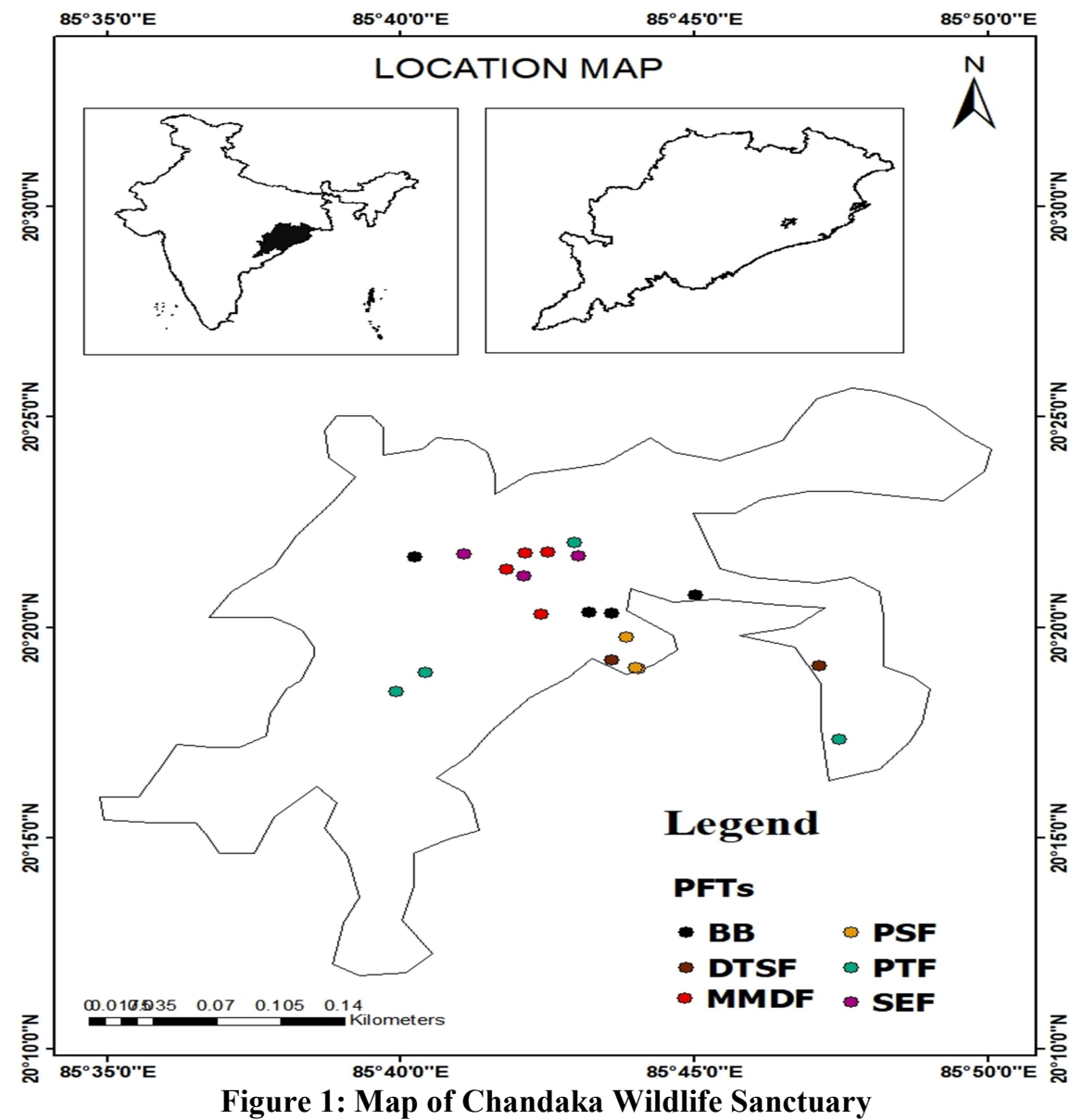

\section{Population structure of woody plant species}

The available GBH data determined the population structure of different plant functional types. The total number of individuals of different girth classes was calculated species-wise for the different plant functional types. From these data, the percent proportion of the population structure of each girth class was calculated for various plant species as:

Percent of Proportion $=\frac{\text { No.of individuals in each girth class }}{\text { Total no.of individuals in all the girth classes }} \times 100$

\section{Species diversity indices}

The community structure and its complexity level were evaluated through Shannon-Wiener's Index or species diversity index $\left(\mathrm{H}^{\prime}\right)$ and Simpson's Index (D) (Whittaker, 1975). Margalef's index (Aslm, 2009) and Pielou's evenness index (Pielou, 1966) were considered for richness, and evenness.

\section{Results and Discussion}

Frequency, density, dominance, IVI, and diversity indices values of six PFTs of 2261 stems were measured. A total of 70 woody plant species belongs to 63 genera, and 35 families (53 trees, 17 shrubs, and 01 herb species) are taken into account for analyzing the vegetation structure, density of different plant functional types and resulting heterogeneous composition among them (Table 1). The dominant families were Rubiaceae $>$ Rutaceae $>$ Euphorbiaceae $>$ Ebenaceae $>$ Combretaceae $>$ Anacardiaceae $>$ Sapotaceae $>$ Fabaceae. A liana C. album exhibited luxuriant growth over tree species and a gymnosperm C. sphaerica commonly observed in all PFTs. The introduced species like Senna siamea, Tectona grandis, Simarouba amara have been successfully adopted in individual pockets of the forests constituting specific plant functional types. 
Table 1: List of plant species having Girth at breast height $\geq 10 \mathrm{~cm}$ along their family and habit identified in Chandaka Wildlife Sanctuary

\begin{tabular}{|c|c|c|}
\hline BOTANICAL NAME & FAMILY I & ABIT \\
\hline 1. Aegle marmelos (L.)Corr. & \begin{tabular}{l|l} 
& Rutaceae \\
\end{tabular} & Tree \\
\hline 2. Alangium salvifolium (L.f.) Wang. & Alangiaceae & Tree \\
\hline 3. Anacardium occidentale L. & Acanthaceae & Tree \\
\hline 4. Antidesma ghaesembilla Gaertn. & Euphorbiaceae & Small Tree \\
\hline 5. Azadirachta indica A Juss. & Meliaceae & Tree \\
\hline 6. Bambusa bambos (L.) Voss. & Poaceae & Woody herb \\
\hline 7. Bauhinia racemosa Lam. & Caesalpiniaceae & Tree \\
\hline 8. Benkara malabarica (Lam.)Tirveng. & Rubiaceae & Thorny Shrub \\
\hline 9. Bridelia retusa (L.) A.Juss. & Euphorbiaceae & Small Tree \\
\hline 10. Buchanania lanzan Spreng. & Anacardiaceae & Tree \\
\hline 11. Careya arborea Roxb. & Barringtoniaceae & Tree \\
\hline 12. Casearia elliptica Willd & Flacourtiaceae & Shrub \\
\hline 13. Cassia fistula $\mathrm{L}$. & Caesalpiniaceae & Tree \\
\hline 14. Chloroxylon swietiana $D C$. & Rutaceae & Small Tree \\
\hline 15. Cipadessa baccifera (Roth) Miq. & Meliaceae & Shrub \\
\hline 16. Cleistanthus collinus (Roxb.)Benth.exHok.f. & Euphorbiaceae & Small tree \\
\hline 17. Combretum album Pers.. & Combretaceae & Shrub \\
\hline 18. Crateva magna (Lour.)Dc. & Capparaceae & Tree \\
\hline 19. Cycas sphaerica Roxb. & Cycadaceae & Shrub \\
\hline 20. Diospyros ferrea (Willd.) Bakh. & Ebenaceae & Shrub \\
\hline 21. Diospyros melanoxylon Roxb & Ebenaceae & Tree \\
\hline 22. Diospyros montana Roxb. & Ebenaceae & Tree \\
\hline 23. Diospyros sylvatica Roxb. & Ebenaceae & Tree \\
\hline 24. Gliricidia sepium (Jacq.)Kunth ex Walp. & Fabaceae & Tree \\
\hline 25. Glochidion zeylanicum (Gaertn.)Juss. & Euphorbiaceae & Tree \\
\hline 26. Glycosmis pentaphylla (Retz.)DC. & Rutaceae & Shrub \\
\hline 27. Grewia tilifolia Vahl & Tiliaceae & Small tree \\
\hline 28. Haldinia cordifolia (Roxb.)ridsd. & Rubiaceae & Tree \\
\hline 29. Helicteres isora $\mathrm{L}$. & Malvaceae & Shrub \\
\hline 30. Holarrhena pubescens (Buch-Ham.)Wall. & Apocynaceae & Tree \\
\hline 31. Hymenodictyon orixense (Roxb.)Mabb. & Rubiaceae & Small Tree \\
\hline 32. Ixora parviflora Vahl. & Rubiaceae & Shrub \\
\hline 33. Ixora undulata Roxb. & Rubiaceae & Shrub \\
\hline 34. Lagerostroemia parviflora Roxb. & Lythraceae & Tree \\
\hline 35. Lannea coromandelica (Houtt.)Merr. & Anacardiaceae & Tree \\
\hline 36. Lepisanthes tetraphylla Radik & Sapindaceae & Tree \\
\hline 37. Madhuca indica J.F.Gmel. & Sapotaceae & Tree \\
\hline 38. Mimosa himalayana Gamble. & Mimosaceae & Shrub \\
\hline 39. Mimusops elengi $L$. & Sapotaceae & Tree \\
\hline 40. Morinda pubescens Sm. & Rubiaceae & Tree \\
\hline 41. Murraya paniculata (L.) Jack & Rutaceae & Shrub \\
\hline 42. Naringi crenulate (Roxb.)Nicolson. & Rutaceae & Shrub \\
\hline 43. Nyctanthes arbour-tristis L. & Oleaceae & Small Tree \\
\hline 44. Olax scandens Roxb. & Olacaceae & Shrub \\
\hline 45. Pavetta crassicaulis Bremek & Rubiaceae & Small Tree \\
\hline 46. Peltophorum pterocarpum (DC.)Baker ex K.Heyne & Caesalpiniaceae & Tree \\
\hline 47. Polyalthia cerasoides (Roxb.)Bedd. & Annonaceae & Tree \\
\hline 48. Pongamia pinnata (L.)Pierre. & Fabaceae & Tree \\
\hline 49. Pterocarpus marsupium Roxb. & Fabaceae & Tree \\
\hline
\end{tabular}




\begin{tabular}{|l|l|l|}
\hline 50. Pterospermum acerifolium (L.)Willd. & Sterculiaceae & Tree \\
\hline 51. Semecarpus anacardium L.f. & Anacardiaceae & Tree \\
\hline 52. Shorea robusta Gaertn.f. & Dipterocarpaceae & Tree \\
\hline 53. Spondias pinnata(L.f.)Kurz & Anacardiaceae & Tree \\
\hline 54. Stereospermum colais (Buch Ham.ex Dillw.) Mabberley & Bignoniaceae & Tree \\
\hline 55. Streblus asper Lour. & Moraceae & Small Tree \\
\hline 56. Strychnos nux-vomica L. & Strychnaceae & Tree \\
\hline 57. Strychnos potatorum L. & Strychnaceae & Tree \\
\hline 58. Syzygium cumini (L.)Skeels. & Myrtaceae & Tree \\
\hline 59. Tamilnadia uliginosa (Retz.)Tirveng. And Sastre & Rubiaceae & Thorny Tree \\
\hline 60. Tarenna asiatica (L.)Kuntze ex Schum. & Rubiaceae & Shrub \\
\hline 61. Tectona grandis L.f. & Lamiaceae & Tree \\
\hline 62. Terminalia alata Heyne ex Roth. & Combretaceae & Tree \\
\hline 63. Terminalia bellirica (Gaertn) Roxb & Combretaceae & Tree \\
\hline 64. Terminalia chebula Retz. & Combretaceae & Tree \\
\hline 65. Toddalia asiatica (L.)Lam. & Rytaceae & Shrub \\
\hline 66. Vitex pinnata L. & Verbenaceae & Shrub \\
\hline 67. Wrightia arborea (Dennst.)Mebb. & Apocynaceae & Small Tree \\
\hline 68. Xantolis tomentosa (Roxb.)Rafin & Sapotaceae & Tree \\
\hline 69. Xylia xylocarpa (Roxb.)Taub. & Mimosaceae & Tree \\
\hline 70. Ziziphus xylopyrus (Retz.)Will. & Rhamnaceae & Tree \\
\hline Total Species-70, Genus-63 & Tree-53,Shrub-17 & \\
\hline
\end{tabular}

\section{Different Plant Functional Types (PFTs)}

The sanctuary vegetation has divided into six plant functional types. The species Bambusa bambos mostly prevailed all the ranges of CWS .This species was introduced by the forest department Govt. of Odisha in the fringe of Sanctuary, but now it occupies $50 \%$ of the total forest areas and become dominant in bamboo brake, plant functional type. Besides a thin population of tree and shrub species like Diospyros melanoxylon, Holarrhena pubescens, Ziziphus oenopolia, Helicteres isora, and Combretum album, etc were intermixed with the B. Bamboo.

The DTSF (Degraded Thorny Shrubby Forest) type of forest is mostly found in a degraded form and the area is covered by some invasive species like Chromolaena odorata, Hyptis sauveolens, and Lantana camara. These forests harbor a very less number of species viz. Ziziphus xylopyrus, Casearia graveolens, Cipadessa baccifera, and Phoenix acqualis, etc. The plotting data on MMDF (Moist Mixed Deciduous Forest) type point out some intermingled species like Xylia xylocarpa, Combretum album, Strychnos nux-vomica, Syzygium cumini, Tectona grandis, Careya arborea, Holarrhena pubescens, Polyalthia cerasoides, Woodfordia fruticosa, Aegle marmelos,
Casearia graveolens and Tarenna asiatica, etc. The PSF (Peninsular Sal Forest) type is dominated by Shorea robusta associated with species like Benkara malabarica, Bauhinia recemosa, Buchanania lanzan, Chloroxylon swetenia, Cleiostanthus collinus, Carissa spinarum, Cipadessa baccifera, Diospyros meneoxylon, Holarrhena pubescens, Mitragyna parviflora, Madhuca longifolia, Terminalia alata, and Vitex pinnata, etc. PTF (Planted Teak Forest) type of vegetation was covered the plantation zone of around 30-35 years. This type was dominated with $\mathrm{T}$. grandis associated with some natural species such as A. marmelos, B. retusa, Diospyros sylvatica, and Ziziphus mauritiana etc.Some patches of SEF (Semi-Evergreen Forest) type vegetation was endorsed by large shrubs and small trees. The notable tree species associated with this PFT were Alangium salvifolium, Bridelia retusa, Careya arborea, Diospyros sylvatica, Lagerstroemia parviflora, Lepisanthes tetraphylla, Naringi crenulate, P. cerasoides, Pterospermum xylocarpum, Shorea robusta, S. nux-vomica, $S$. cumini, Terminalia alata, and Terminalia bellerica etc. The shrubby elements, namely $H$. pubescens, Flacourtia indica, Meyna spinosa and climbers like Combretum album, was also frequently observed 
here. These areas were dominated by $X$. xylocarpa (Table 1). The IVI of individual species were sparsely distributed along with different PFTs (Figure 2). Considering IVI of species like $X$. xylocarpa (18.45), A. marmelos (2.95), C. arborea (4.59), C. eliptica (3.05), C. ruxburgii (7.29), L.parviflora (7.26), M. indica (8.50), N. crenulata (2.30), P. emblica (2.76), P cerasoides (5.23), S.cumini (3.37), and Z. xyloparus (2.34) etc. were frequent in the 5 functional types except BB type (Figure

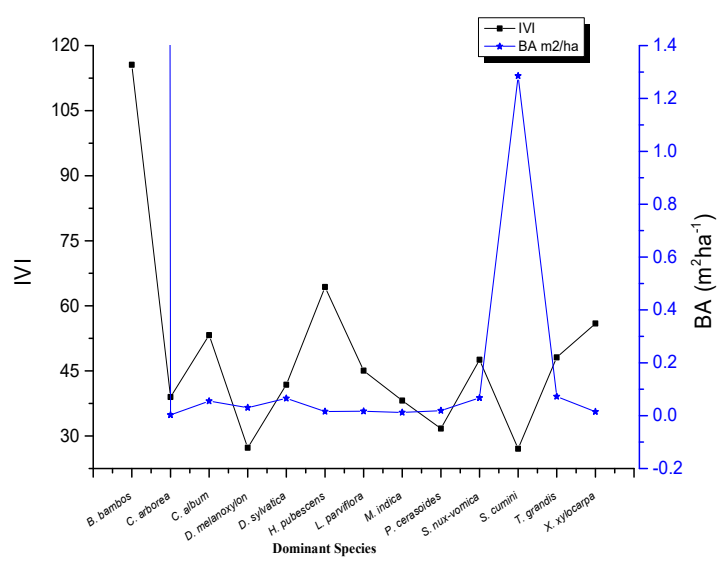

Figure 2: Comparison of IVI and basal area (BA) of some dominant species of the sanctuary

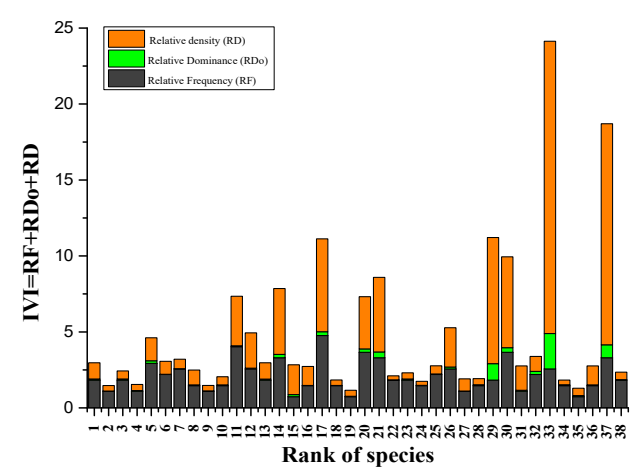

Figure 3: IVI (Relative Frequency, Relative Dominance and Relative Density) of few dominant plant species observed in Chandaka Wildlife Sanctuary, the rank of species derived from table 2

The estimated basal area in MMDF was $0.23 \mathrm{~m}^{2} / \mathrm{ha}$. However, the basal area of species in SEF and PTF type ranged from 0.007 to $3.12 \mathrm{~m}^{2} /$ ha and 0.016 to $494 \mathrm{~m}^{2} /$ ha respectively. The Bamboo brake (BB) was purely dominated by $B$. bamboo with the highest basal area among all PFTs i.e. $663.18 \mathrm{~m}^{2} /$ ha. The Thorny shrubby vegetation of DTSF type obtained lowest basal area ranged from 0.002 to $0.17 \mathrm{~m}^{2} / \mathrm{ha}$. Here some of the species having lower IVI occupied large basal areas due to their high girth values like $M$. indica $\left(0.32 \mathrm{~m}^{2} / \mathrm{ha}\right), L$. parviflora $\left(0.24 \mathrm{~m}^{2} / \mathrm{ha}\right)$, and $P$. cerasoides $(0.15$ $\mathrm{m}^{2} / \mathrm{ha}$ ), etc. (Table 2 ). The $\mathrm{A} / \mathrm{F}$ ratio ranged from 0.06-2.79 that indicate contiguous distribution of the species along the 6 PFTs.

Species Distribution along GBH range, density and basal area

The population structure analysis revealed that highest percentage $(31.79 \%)$ of tree population was found in the GBH class of $10-20 \mathrm{~cm}$. While $1 \%$ trees were found in $71-80 \mathrm{~cm}$ GBH class and lower tree percent proportion $(0.19 \%)$ was observed at GBH range $>100$ (Figure 4) except Bamboo brake type. Further, the population structure for five PFTs gradually decreased with an increase in girth classes. The percent proportion of five PFTs were in the order of PTF $(28.68 \%)<\operatorname{SEF}(23.34 \%)<$ MMDF $(21.50 \%)<$ PSF $(21.45 \%)<$ DTSF $(5 \%)$ for all girth classes and were found higher for species like $T$. grandis, $X$. xylocarpa, $S$. robusta, $B$. bambo, $H$. pubescens, L. parviflora, $M$. indica, $D$. sylvatica, etc.

The average density (1637 individuals $\mathrm{ha}^{-1}$.) was highest in the GBH class of $10-20 \mathrm{~cm}$ with a basal area of $3.15 \mathrm{~m}^{2} \mathrm{ha}^{-1}$. Rather highest basal area $\left(11.38 \mathrm{~m}^{2} \mathrm{ha}^{-1}\right)$ calculated in the GBH class of $30-40$ $\mathrm{cm}$. The species like $T$. grandis (3170 individuals $\left.\mathrm{ha}^{-1}\right), X$. xylocarpa (3060 individuals $\left.\mathrm{ha}^{-1}\right), H$. pubescens (1280 individual ha $\left.{ }^{-1}\right)$, S. robusta $(1240$ individual $\left.\mathrm{ha}^{-1}\right), S$. nux-vomica (1120 individuals $\left.\mathrm{ha}^{-1}\right), D$. sylvatica $\left(880\right.$ individuals ha $\left.{ }^{-1}\right)$, B. bambos (770 individuals $\mathrm{ha}^{-1}$ ) and $M$. indica $(760$ individuals ha ${ }^{-1}$ ), etc have higher density. The stem densities of PFTs were observed in following order Planted teak forest $(\mathrm{PTF})>$ Semi-evergreen forest $(\mathrm{SEF})>$ Moist mixed deciduous forest $(\mathrm{MMDF})>$ Peninsular sal forest (PSF) > Degraded thorny shrubby forest (DTSF) $>$ Bamboo brakes (BB).In the case of BB type, the density (42 clump ha ${ }^{-1}$ ) was highest in $150-200 \mathrm{~cm}$ GBH class, but the basal area $\left(149.55 \mathrm{~m}^{2} \mathrm{ha}^{-1}\right)$ was highest in between the GBH class of $750-850 \mathrm{~cm}$ (Figure 5(B)). The highest number of species observed in the girth class of $10-20 \mathrm{~cm}$. The mean basal area of this was $0.63 \mathrm{~m}^{2} \mathrm{ha}^{-1}$. In figure 5(A), it has been seen that the density was highest at the lowest basal area. Similarly, for Bamboo brakes, (Figure 5B) the basal 


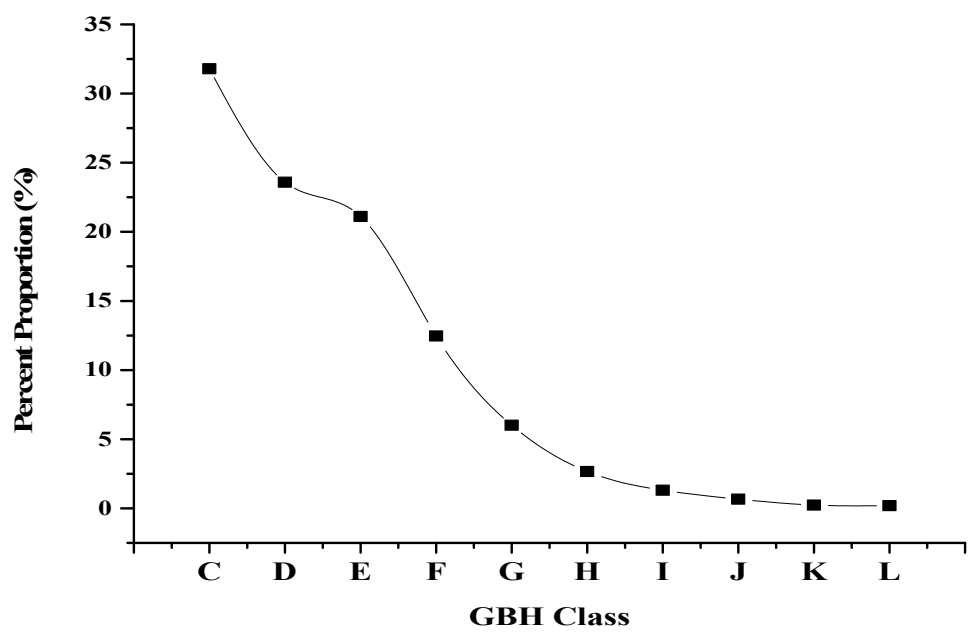

Figure 4: Population Structure of Plant species. The GBH classes were categorized as the following notations $C=10-20, D=21-30, E=31-40, F=41-50, G=51-60, H=61-70, I=71-80, J=81-90, K=91-100$ and $L>101$ etc
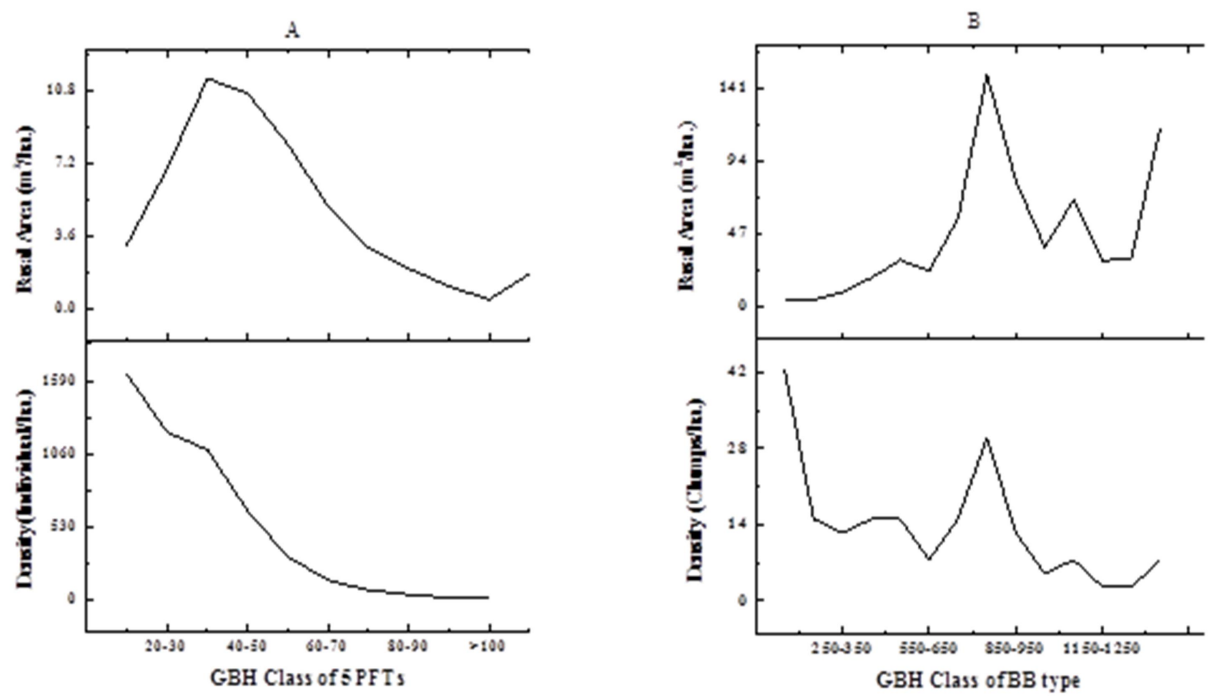

Figure 5: Density and basal area of discrete GBH class of PFTs. A. Five plant functional type's B. bamboo brake type

area was highest at the lower GBH class i.e., 150$200 \mathrm{~cm}$. The ascending order of basal area among 6 PFTs were estimated as DTSF $\left(0.92 \mathrm{~m}^{2} \mathrm{ha}^{-1}\right)<$ $\operatorname{MMDF}\left(8.62 \mathrm{~m}^{2} \mathrm{ha}^{-1}\right)<\operatorname{SEF}\left(11.12 \mathrm{~m}^{2} \mathrm{ha}^{-1}\right)<\operatorname{PSF}$ $\left(11.63 \mathrm{~m}^{2} \mathrm{ha}^{-1}\right)<\operatorname{PTF}\left(18.54 \mathrm{~m}^{2} \mathrm{ha}^{-1}\right)<$ BB $(663.18$ $\left.\mathrm{m}^{2} \mathrm{ha}^{-1}\right)$. The basal areas were higher in the GBH class range of $30-50 \mathrm{~cm}$ in all PFTs. The higher basal areas occupying species were $T$. grandis $(0.34$ $\left.\mathrm{m}^{2} \mathrm{ha}^{-1}\right), S$. nux-vomica $\left(0.09 \mathrm{~m}^{2} \mathrm{ha}^{-1}\right), X$. xylocarpa $\left(0.09 \mathrm{~m}^{2} \mathrm{ha}^{-1}\right), M$. indica $\left(0.08 \mathrm{~m}^{2} \mathrm{ha}^{-1}\right), S$. cumini $\left(0.06 \mathrm{~m}^{2} \mathrm{ha}^{-1}\right), P$. cerasoides $\left(0.05 \mathrm{~m}^{2} \mathrm{ha}^{-1}\right), L$. parviflora $\left(0.05 \mathrm{~m}^{2} \mathrm{ha}^{-1}\right)$, D. montana $\left(0.04 \mathrm{~m}^{2}\right.$ ha $\left.{ }^{1}\right)$, A. marmelos $\left(0.03 \mathrm{~m}^{2} \mathrm{ha}^{-1}\right), P$. acerifolium $(0.02$ $\left.\mathrm{m}^{2} \mathrm{ha}^{-1}\right)$, B. retusa $\left(0.02 \mathrm{~m}^{2} \mathrm{ha}^{-1}\right), D$. melanoxylon $\left(0.02 \mathrm{~m}^{2} \mathrm{ha}^{-1}\right), T$. bellirica $\left(0.01 \mathrm{~m}^{2} \mathrm{ha}^{-1}\right), C$. elliptica $\left(0.004 \mathrm{~m}^{2} \mathrm{ha}^{-1}\right)$.

\section{Species diversity indices}

The species composition patterns and distribution through measuring GBH, IVI, and species diversity indices were calculated to establish the structural and compositional attributes of several species at different Plant Functional Types. The concentration 
of species richness (Margalef index) was highest in Semi-Evergreen forest (SEF) type and lowest in bamboo brakes (BB). However, Evenness was lower at PTF (0.4) indicated that only a few dominant species, while higher evenness observed at BB type (1.0), SEF type (0.58) exposed an equal number of individuals belong to each species. The species richness among PFTs were SEF $>$ MMDF $>$ $\mathrm{PSF}>\mathrm{PTF}>\mathrm{DSTF}>\mathrm{BB}$, whereas evenness was BB $>$ DTSF $>$ MMDF $>$ SEF $>$ PSF $>$ PTF. The number of species found in each PFTs were MMDF $>\mathrm{SEF}>\mathrm{PSF}>\mathrm{DTSF}>\mathrm{PTF}>\mathrm{BB}$ and the ascending order of stem densities were PTF $>$ SEF $>\mathrm{MMDF}>\mathrm{SEF}>\mathrm{PSF}>\mathrm{DTSF}>\mathrm{BB}$. The Shannon-Wiener Index for BB was lower $\left(\mathrm{H}^{\prime} \sim 0\right)$ reflecting low community complexity, whereas, for $\mathrm{SEF}$, it was $\mathrm{H}^{\prime}=2.31$ indicating higher community complexity. Both the Shannon diversity $(0-2.20)$ and Simpson's index (0-0.85) among all PFTs were following the order of SEF $>$ MMDF $>$ DTSF $>$ PSF $>$ PTF $>$ BB (Table-3). The range of species richness was 0-3.69 in five PFTs, and for the Bamboo Brakes type, it was 0.

The degrees of predicting individual species of a community are uncertain. The environmental factors such as temperature, precipitation , elevation and land topology etc. affect the species composition of the different forest types. The IVI value was measured highest for the species viz. $T$. grandis , X. xylocarpa , H. pubescens , S. nuxvomica, C. roxburghii, B. bambos, L. parviflora, $M$. indica, $P$. cerasoides contributing higher basal area. However, species like $T$. grandis (23.80), $S$. robusta (11.07) and B. bambos (97.34) were predominant in their specific vegetation group occupied higher IVI values. The Abundance to frequency ratio (table-2) of species indicated the contiguous distribution range of species and was in between 0.05-2.79 which was common in nature. Few species show random distribution consequence uneven distribution of vegetation pattern in all the plant functional types (Sahu et al., 2012).

The stand density of six PFTs ranged from 4201477 individual/ha with an average value of 883 individual/ha. The stem densities of PFTs were observed in following order Planted teak forest $(\mathrm{PTF})>$ Semi-evergreen forest $(\mathrm{SEF})>$ Moist mixed deciduous forest (MMDF) $>$ Peninsular sal forest $(\mathrm{PSF})>$ Degraded thorny shrubby forest (DTSF) $>$ Bamboo brakes (BB).The estimation was similar to the deciduous forest of Similipal biosphere reserve, Odisha (848-957 ind. ha ${ }^{-1}$, Mohanta et al., 2020), tropical dry deciduous forest of central India (702-1671 ind. ha ${ }^{-1}$,Joshi et al., 2019) moist deciduous forest of Eastern India (355741 ind. ha ${ }^{-1}$, T. Sahoo et al., 2017), fragmented moist deciduous forest of Tripura, India (428-884 ind. $\mathrm{ha}^{-1}, \mathrm{~K}$. Majumdar, 2014). The value is much higher than the tropical deciduous forest of Northcentral Eastern Ghats, India (395-573 ha ${ }^{-1}$, Naidu et al., 2018). Eastern Ghats of Northern Andhra Pradesh (639-836 ha-1, Reddy et al., 2011). The differences in the present and previous studies were attributable to the inequality distribution of species in different plant functional types. The average stand density in each plot was 82 individuals/plot and it has controlled the GBH. In our study the low density GBH distribution resulted more heterogeneous condition found under high stand density (Threon, 2004). The average number of species present in all plots was observed as 10 species that were similar to the deciduous forest of Andhra Pradesh, the southern of Eastern Ghats (Naidu et al., 2016). Here the structure and composition of forests related to species diversity and higher species diversity is directing more complex forest structures (Huang et al., 2003).The population structure of tree species distribution graph reveals a reverse J-shaped curve. Among the 5 PFTs, the GBH ranged from 10-110 cm except for Bamboo Brake(BB) type (ranged 50-1450 cm). The curve implied the lower GBH class $(10-20 \mathrm{~cm})$ has large number of individual inferred good regeneration potential and lead to profound environmental changes. Hence, the regular evaluation of vegetation structure analysis of these forests is required.

The different altitude species densities, age of woody species, girth class, and their distribution regulate the basal area. The density and basal area were indicated a similar pattern of alignment with the increased $\mathrm{GBH}$ range for the five plant functional types. In fig. 5(A), it has been seen that the density was highest at the lowest basal area. Similarly, for Bamboo brakes, (Fig.5B) the basal area was highest at the lower GBH class i.e., 150$200 \mathrm{~cm}$. After the GBH class of $450-550 \mathrm{~cm}$, the density and basal area referred to a similar kind of alignment along with the increase of the GBH class. The ascending order of basal area among 6 PFTs 
Table 2: IVI, BA and distribution pattern of dominant species in different plant functional types of Chandaka Wildlife Sanctuary

\begin{tabular}{|c|c|c|c|c|}
\hline Rank of sp. & Species & $\mathrm{BA}(\mathrm{m} 2 / \mathrm{ha})$ & $\mathrm{A} / \mathrm{F}$ & IVI \\
\hline 1. & Aegle marmelos & 0.08 & 0.23 & 2.95 \\
\hline 2. & Alangium salvifolium & 0.01 & 0.21 & 1.46 \\
\hline 3. & Bambusa bambos & 110.53 & 1.14 & 97.34 \\
\hline 4. & Bridelia retusa & 0.08 & 0.12 & 2.43 \\
\hline 5. & Buchanania lanzan & 0.05 & 0.24 & 1.54 \\
\hline 6. & Careya arborea & 0.20 & 0.13 & 4.59 \\
\hline 7. & Casearia eliptica & 0.02 & 0.13 & 3.05 \\
\hline 8. & Cassia fistula & 0.02 & 0.07 & 3.19 \\
\hline 9. & Chloroxylon swietenia & 0.06 & 0.33 & 2.48 \\
\hline 10. & Cipadessa baccifera & 0.02 & 0.21 & 1.47 \\
\hline 11. & Cleistanthus collinus & 0.05 & 0.18 & 2.04 \\
\hline 12. & Combretum roxburghii & 0.07 & 0.14 & 7.29 \\
\hline 13. & Diospyros melanoxylon & 0.07 & 0.25 & 4.90 \\
\hline 14. & Diospyros montana & 0.08 & 0.23 & 2.95 \\
\hline 15. & Diospyros sylvatica & 0.27 & 0.29 & 7.78 \\
\hline 16. & Gliricidia sepium & 0.17 & 2.64 & 2.80 \\
\hline 17. & Helicteres isora & 0.02 & 0.42 & 2.71 \\
\hline 18. & Holarrehena pubescens & 0.29 & 0.19 & 11.02 \\
\hline 19. & Ixora undulata & 0.02 & 0.12 & 1.83 \\
\hline 20. & Kigelia africana & 0.04 & 0.54 & 1.16 \\
\hline 21. & Lagerostroemia parviflora & 0.26 & 0.18 & 7.26 \\
\hline 22. & Madhuca indica & 0.46 & 0.33 & 8.50 \\
\hline 23. & Morinda pubescens & 0.02 & 0.06 & 2.11 \\
\hline 24. & Naringi crenulate & 0.09 & 0.09 & 2.30 \\
\hline 25. & Olax scandens & 0.02 & 0.09 & 1.74 \\
\hline 26. & Phyllanthus emblica & 0.04 & 0.08 & 2.76 \\
\hline 27. & Pollyalthia cerasoides & 0.15 & 0.28 & 5.23 \\
\hline 28. & Pongamia pinnata & 0.01 & 0.48 & 1.90 \\
\hline 29. & pterospermum xylocarpum & 0.07 & 0.14 & 1.92 \\
\hline 30. & Shorea robusta & 1.29 & 1.79 & 11.07 \\
\hline 31. & Strychnos nux-vomica & 0.35 & 0.32 & 9.84 \\
\hline 32. & Strychnos potatorum & 0.07 & 0.96 & 2.74 \\
\hline 33. & Syzygium cumini & 0.25 & 0.15 & 3.37 \\
\hline 34. & Tectona grandis & 2.78 & 2.11 & 23.80 \\
\hline 35. & Terminalia bellerica & 0.07 & 0.11 & 1.83 \\
\hline 36. & Terminalia chebula & 0.09 & 0.66 & 1.29 \\
\hline 37. & Xantolis tomentosa & 0.06 & 0.42 & 2.74 \\
\hline 38. & Xylia xylocarpa & 1.02 & 0.97 & 18.45 \\
\hline 39. & Ziziphus xyloparus & 0.03 & 0.11 & 2.34 \\
\hline
\end{tabular}

$\mathrm{A}=$ Abundance, $\mathrm{F}=$ Frequency 
Table 3: Diversity Indices for six Plant Functional Types

\begin{tabular}{|c|c|c|c|c|c|c|}
\hline \multirow[t]{2}{*}{ Diversity Indices } & \multicolumn{6}{|l|}{ PFTs } \\
\hline & BB & DTSF & MMDF & PSF & PTF & SEF \\
\hline Species richness & 1 & 9 & 15 & 11 & 10 & 18 \\
\hline Stem density ind./ha) & $190^{*}$ & 503 & 1107 & 1090 & 1500 & 1202 \\
\hline Species Number & 1 & 26 & 38 & 29 & 24 & 37 \\
\hline GBH range $(\mathrm{cm})$ & $50-1432$ & $10-40$ & $20-90$ & $10-70$ & $10-100$ & $10-90$ \\
\hline Basal Area $\left(\mathrm{m}^{2} \mathrm{ha}^{-1}\right)$ & $\begin{array}{ll}265.27 \quad \pm \\
11.2\end{array}$ & $0.93 \pm 1.7$ & $8.64 \pm 0.58$ & $9.24 \pm 0.9$ & $77.27 \pm 16.8$ & $11.12 \pm 1.0$ \\
\hline Dominance D & 1 & 0.21 & 0.12 & 0.23 & 0.43 & 0.14 \\
\hline Simpson's index (1-D) & 0 & 0.78 & 0.84 & 0.76 & 0.56 & 0.85 \\
\hline Shannon index $\left(\mathrm{H}^{\prime}\right)$ & 0 & 1.80 & 2.20 & 1.75 & 1.32 & 2.31 \\
\hline Evenness $\mathrm{e}^{\wedge} \mathrm{H} / \mathrm{S}$ & 1 & 0.71 & 0.61 & 0.53 & 0.40 & 0.58 \\
\hline Margalef & 0 & 1.93 & 4.83 & 2.13 & 1.77 & 3.69 \\
\hline Menhinick & 0.23 & 1.27 & 1.53 & 1.00 & 0.71 & 1.55 \\
\hline
\end{tabular}

*Clumps/ha

Table 4: Summary of One-Way ANOVA of Basal Area and IVI

\begin{tabular}{|l|l|l|l|l|l|}
\hline \multicolumn{2}{|c|}{ Source of Variance } & df & SS & MSS & F-value \\
\hline $\begin{array}{l}\text { BA } \\
\text { IVI }\end{array}$ & 62 & 2.76 & 2.765 & 40.63 \\
$\mathrm{P}<0.05$
\end{tabular}

were estimated as DTSF $\left(0.92 \mathrm{~m}^{2} \mathrm{ha}^{-1}\right)<$ MMDF $\left(8.62 \mathrm{~m}^{2} \mathrm{ha}^{-1}\right)<\operatorname{SEF}\left(11.12 \mathrm{~m}^{2} \mathrm{ha}^{-1}\right)<\operatorname{PSF}(11.63$ $\left.\mathrm{m}^{2} \mathrm{ha}^{-1}\right)<\operatorname{PTF}\left(18.54 \mathrm{~m}^{2} \mathrm{ha}^{-1}\right)<\mathrm{BB}\left(663.18 \mathrm{~m}^{2}\right.$ ha $\left.{ }^{1}\right)$. The stem densities of PFTs were observed in following order Planted teak forest $(\mathrm{PTF})>$ Semievergreen forest $(\mathrm{SEF})>$ Moist mixed deciduous forest $(\mathrm{MMDF})>$ Peninsular sal forest $(\mathrm{PSF})>$ Degraded thorny shrubby forest (DTSF) $>$ Bamboo brakes (BB). The average basal areas of all the PFTs were estimated as $9.33 \pm 1.67 \mathrm{~m}^{2} \mathrm{ha}^{-1}$ ).

The estimated basal area was similar to Dry forest of Miombo, Zambia $\left(16.5 \mathrm{~m}^{2} \mathrm{ha}^{-1}\right.$, Kalaba et al., 2013). However, the result was much lower in comparison to other forests of India as in Deciduous and semi-evergreen forest of Similipal biosphere reserve $\left(35.74 \mathrm{~m}^{2} \mathrm{ha}^{-1}\right.$, Mahanta et al., 2021) ,Temperate Forest of Kashmir and MandalChoota Garhwal Himalaya $\left(35.65 \mathrm{~m}^{2} \mathrm{ha}^{-1}\right.$ and 59.66 $\mathrm{m}^{2} \mathrm{ha}^{-1}$, Dar and Sundarpandian, 2016, Gairola et al., 2012), Tropical moist deciduous forest of Uttar Pradesh (35.19 $\mathrm{m}^{2} \mathrm{ha}^{-1}$, Tripathi \& Singh, 2009), Semi-evergreen forest of Cambodia $\left(22.2 \mathrm{~m}^{2} \mathrm{ha}^{-1}\right.$, Chheng et al., 2016).

The one-way ANOVA of IVI and Basal area obtained f-value 40.63 have significant differences resulting in the existence of a mean difference between basal area and IVI. The correlation between basal Area and IVI values among all species was significant at 0.001 levels. The mean of the basal area increased with the IVI values. But in cases, the higher basal area obtained lower IVI that may happen due to the high GBH of the species. The coefficient of correlation of Basal area and species density were 0.89 and 0.35 was significant at $99 \%$ and $95 \%$ respectively. This could be predicted the basal area and species density have a joint contribution to species distribution. The calculated $r^{2}(1.0)$ has very minutely differed with adjusted $r^{2}$ values. Hence, the dependent variables basal area and density may be used significantly for the determination of IVI and species distribution.

Both the Shannon diversity (0-2.20) and Simpson's index (0-0.85) among all PFTs were following the order of SEF $>$ MMDF $>$ DTSF $>$ PSF $>$ PTF $>$ BB (table-3). The range of species richness was 0-3.69 in five PFTs, and for the Bamboo Brakes type, it was 0 . This results were equivalent to Temperate forest of Mandal-Choota Garhwal, Himalaya (Gairola et al., 2012), Community temperate forest Nepal (Kunwar and Sharma, 2004), Temperate forest Garhwal, Himalaya (Raturi, 2012), Subtropical forest, and North-Western Himalaya (Sharma \& Raina, 2013).Species richness were lower in comparison to the tropical evergreen forest of Western Ghats of Karnataka, India (Sathish, 2013). 
The species richness and composition be affected by the age structure of forest types, climatic conditions, and anthropogenic disturbances, etc. (Padalia et al., 2004). The forest with high tree diversity revealed higher diversity indices (Adekunle et al., 2013). The Menhinick index 0.231.77 , indicates regeneration woody species. The range of biodiversity and abundance of species could be assessed through the biodiversity indices. The Shannon- Wiener diversity index ranged from 0.81-4.1 (Sahu et al., 2012), Undarpandian \& Swamy, 2000) denotes moderate community complexity of a forest and the study estimated the 1.33-2.32 fall within this range (Table 2). Whereas the Shannon-Wiener Index of deciduous forest of Andhra Pradesh, the southern of Eastern Ghats 3.76 - 3.96 was indicating higher species diversity in comparison to our study. The lower ShannonWiener Index of Bamboo brakes was reflecting low community complexity and higher index observed in Semi-evergreen forest $\left(\mathrm{H}^{\prime}=2.32\right)$ indicating higher community complexity. Both the Shannon diversity and Simpson's index among all PFTs were following the order of Semi-Evergreen Forest $(\mathrm{SEF})>$ Moist Mixed Deciduous Forest $(\mathrm{MMDF})>$ Degraded Thorny Shrubby Forest (DTSF) > Peninsular Sal Forest (PSF) $>$ Planted Teak Forest $(\mathrm{PFT})>$ Bamboo Brakes (BB). The Simpson index within the range of 0.21-1.34 of forests discriminated the mixed nature of vegetation with more species diversity (Lalfakawma et al., 2009) was observed in the 5 PFTs i.e. MMDF, SEF, DTSF, PSF, and TPF, etc. The resulted margalef index (0-3.69) has lower value than tropical forests (Sathish et al., 2013).

\section{Conclusion}

The study region is now under the protection of the State Government; still, it faces the overexploitation of wood for commercialization and forest fires during summer. This Quantitative

\section{References}

Adekunle, V. A. J., Olagoke, A. O., \& Ogundare, L. F. (2013). Logging impacts in tropical lowland humid forest on tree species diversity and environmental conservation. Applied Ecology and Environmental Research, 11(3), 491-511. information on the forest structure and composition of CWS will be implemented for the conservation and management of CWS. The presence of low species richness, moderate stand density, and diversity indices indicated the heterogeneous species composition of the forest. The Shannon diversity and Simpson's Index stated moderate phyto-diversity of Chandaka wildlife sanctuary mainly dominated by B. bamboo, T. grandis, $X$. xylocarpa, $S$. robusta, $H$. pubescens, Diospyros species, etc. and the Menhinick index inferred this as a regenerated forest with species heterogeneity The study of the interrelationship among basal area, stem density, and IVI through ANOVA, correlation, and regression may predict that they have a significant correlation with each other and these parameters may significantly apply for the determination of linear models. Hence, this interpreted data is one of the primary inputs for conserving this secondary regenerated forest.

\section{Acknowledgements}

The authors are indebted to the Principal Chief Conservator of Forests, Government of Odisha, India for granting the permission to work in the forest. The Department of Science and Technology, Odisha is acknowledged for financial assistance of Biju Patnaik Research Fellowship to Subhashree Pattnayak. The team wishes to convey a deep sense of gratitude to Director, CSIR-IMMT, Bhubaneswar, for the laboratory facilities. We are also thankful to the Head, School of Life Sciences, Sambalpur University, Sambalpur for co-operation to do this research work. Thanks to the Department of Botany, Maharaja Sriram Chandra Bhanja Deo University, Baripada for doing collaborative research. We are pleased to acknowledge the help rendered by the Division Forest Officer of Chandaka Wildlife Sanctuary, Rangers of Chandaka and Bhubaneswar division, and forest officials during our various survey trips.

Biswal AK, Thatoi HN \& Sahu D. (2005). Floral diversity in Chandaka Wildlife Sanctuary, Orissa. J. Econ. Taxon. Bot. 29(2): 385-394.

Chazdon, R. L., \& Guariguata, M. R. (2016). Natural regeneration as a tool for large-scale forest restoration in the tropics: prospects and challenges. Biotropica, 48(6), 716-730 
Chheng, K., Saski, N., Mizoue, N., Khorn, S., Kao, D., \& Lowe, A. (2016). Assessment of carbon stock of semievergreen forests in Cambodia. Global Ecology and Conservation, 5, 34-47.

Chittibabu, C.V., \& Parthasarathy, N. (2000). Attenuated tree species diversity in human-impacted tropical evergreen forest sites at Kolli Hills, Eastern Ghats, Indian. Biodiversity and Conservation, 9(11), 1493-1519.

Dar, J.A., \& Sundarapandian, S. (2016). Patterns of plant diversity in seven temperate forest types of Western Himalaya, India. Journal of Asia-Pacific Biodiversity, 9 (3), 280-292.

Djuikouo, M.N.K., Doucet, J.L., Nguembou, C.K., Lewis, S.L., \& Sonke, B. (2010). Diversity and aboveground biomass in three tropical forest types in the Dja Biosphere Reserve, Cameroon. African Journal of Ecology, 48(4),1053-1063.

FAO. 2020. Global forest resources Assessment 2020-key findings. Rome

Gairola, S., Sharma, C.M., Ghildiyal, S.K., \& Suyal, S. (2012).Chemical properties of soils concerning forest composition in moist temperate valley slopes of Garhwal Himalaya, India. The Environmentalist, 32,512-523.

Haripriya, G.S. (2000). Estimates of biomass in Indian forests. Biomass and Bioenergy, 19(250), 245-258.

Huang, W., Pohjonen, V., Johansson, S., Nashanda, M., Katigula, M. I. L., \& Luukkanen, O. (2003). Species diversity, forest structure and species composition in Tanzanian tropical forests. Forest ecology and management, 173(1-3), 11-24.

Intergovernmental panel on climate change (2007). Couplings between changes in the climate system and biogeochemistry. Cambridge, University Press, Cambridge.

Joshi, R.K., Dhyani, S., Biomass, carbon density and diversity of tree species in tropical dry deciduous forests in Central India, Acta Ecol. Sin. 39 (4) (2019) 289-299.

Kalaba, F.K., Quinn, C.H., Dougill, A.J., \& Vinya, R. (2013). "Floristic composition, species diversity and carbon storage in charcoal and agriculture fallows and management implications in Miombo woodlands of Zambia." Forest Ecology and Management, 304, 99-109.

Kunwar, R.M., \& Sharma, S.P. (2004).Quantitative analysis of tree species in two community forests of Dolpha district, mid-west Nepal. Himalayan Journal of Sciences, 2(3),2328.

Lalfakawma, Sahoo,U.K., Roy, S., Vanlalhriatpuia, K., \& Vanalalhluna, P.C. (2009). Community composition and tree population structure in undisturbed and disturbed tropical semi-evergreen forest stand of North-East India.
Applied Ecology and Environmental Research ,7, 303318.

Lazos-Chavero, E., Zinda, J., Bennett-Curry, A., Balvanera, P., Bloomfield, G., Lindell, C., \& Negra, C. (2016). Stakeholders and tropical reforestation: challenges, tradeoffs, and strategies in dynamic environments. Biotropica, 48(6), 900-914.

Majumdar, K., Shankar, U., \& Datta, B. K. (2014). Trends in tree diversity and stand structure during restoration: a case study in fragmented moist deciduous forest ecosystems of Northeast India. Journal of Ecosystems, ,1-10.

Mohanta, M. R., Mohanta, A., Mohapatra, U., Mohanty, R. C., \& Sahu, S. C. (2020). Carbon stock assessment and its relation with tree biodiversity in Tropical Moist Deciduous Forest of Similipal Biosphere Reserve, Odisha, India. Tropical Ecology, 61(4), 497-508.

Mueller-Dombois, D., \& Ellenberg, H. (1974). Aims and methods of vegetation ecology, John Wiley and Sons, New York. 45-66.

Naidu, M.T., \& Kumar, O.A. (2016). Tree diversity, stand structure, and community composition of tropical forests in Eastern Ghats of Andhra Pradesh, India. Journal of AsiaPacific Biodiversity, 9(3),328-334.

Ndah, N. R., Andrew, E. E., \& Bechem, E. (2013). Species composition, diversity and distribution in a disturbed Takamanda Rainforest, South West, Cameroon. African Journal of Plant Science, 7(12), 577-585.

Padalia, H., Chauhan, N., Porwal, M.C., \& Roy, P.S. (2004). Phytosociological observations on tree species diversity of Andaman Islands, India. Current Science, 87, 799-806.

Panda, D.K., Kumar, A.,Ghosh, S., Mohanty, R.K. (2013). Stream flow trends in the Mahanadi River basin (India): Linkages to tropical climate variability. Journal of Hydrology, 495, 135-149.

Pearson, T. R., Brown, S., Murray, L., \& Sidman, G. (2017). Greenhouse gas emissions from tropical forest degradation: an underestimated source. Carbon balance and management, 12(1), 1-11.

Pielou, E. C. (1966). Species-diversity and pattern-diversity in the study of ecological succession. Journal of theoretical biology, 10(2), 370-383.

Purvis, A., \& Hector, A. (2000). Getting the measure of biodiversity. Nature, 405(6783), 212-219.

Raturi, G. P. (2012). Forest community structure along an altitudinal gradient of district Rudraprayag of Garhwal Himalaya, India. Ecologia, 2(3),76-84.

Reddy, C. S., Babar, S., Amarnath, G., \& Pattanaik, C. (2011). Structure and floristic composition of tree stand in tropical 
forest in the Eastern Ghats of Andhra Pradesh, India.Journal of Forest Research, 22(4), 491-500.

Sahoo, T., Panda, P. C., \& Acharya, L. (2017). Structure, composition and diversity of tree species in tropical moist deciduous forests of Eastern India: a case study of Nayagarh Forest Division, Odisha. Journal of Forestry Research, 28(6), 1219-1230.

Sahu, S.C., Dhal, N.K., Reddy, C.S., Pattanaik, C., \& Brahmam, M. (2007). Phytosociological study of tropical dry deciduous forest of Boudh district, Orissa, India. Research Journal of forestry, 1(2), 66-72.

Sahu, S.C., Dhal, N.K.,\& Mohanty, R.C. (2012). Tree species diversity and soil nutrient status in a tropical sacred forest ecosystem on Niyamgiri hill range, Eastern Ghats, India. Tropical Ecology, 53,163-168.

Sathish, B. N., Viswanath, S., Kushalappa, C. G., Jagadish, M. R., \& Ganeshaiah, K. N. (2013). Comparative assessment of floristic structure, diversity and regeneration status of tropical rain forests of Western Ghats of Karnataka, India. Journal of Applied and Natural Science, 5(1), 157-164.
Saxena, H.O., \& Brahmam, M. (1994-1996). The flora of Orissa, vol. I-IV. Regional Research laboratory (CSIR), Bhubaneswar, and Orissa Forest Development Corporation Ltd. Bhubaneswar.

Sharma, N., \& Raina, A.K. (2013). Composition, structure and diversity of tree species along an elevational gradient in Jammu province of north-western Himalayas, Jammu, and Kashmir. Indian Journal of Biodiversity and Environmental Sciences, 3(10),12-23.

Tauro, A., Gómez-Baggethun, E., García-Frapolli, E., Chavero, E. L., \& Balvanera, P.(2018). Unraveling heterogeneity in the importance of ecosystem services. Ecology and Society, 23(4).

Tripathi, K.P., \& Singh, B. (2009). Species diversity and vegetation structure across various strata in natural and plantation forests in Katerniaghat wildlife sanctuary, North India.Tropical Ecology, 50(1), 191-200.

Whittaker, R.H., \& Likens, G.E.(1975). The biosphere and man. In Primary productivity of the biosphere. Springer, Berlin, Heidelberg.305-328. 